\title{
Posterior Tooth
}

National Cancer Institute

\section{Source}

National Cancer Institute. Posterior Tooth. NCI Thesaurus. Code C52666.

Refers to teeth and tissues towards the back of the mouth (distal to the canines):

maxillary and mandibular premolars and molars. The designation of permanent posterior teeth in the Universal tooth numbering system include teeth 1 through 5 and 12 through 16 (maxillary), and 17 through 21 and 28 through 32 (mandibular); primary teeth in the Universal tooth numbering system are designated A, B, I, and J (maxillary) and K, L, S, and T (mandibular). 